\title{
Identifying Destination Image of Rural Areas: The Case of Brookings, South Dakota
}

\author{
Chinomso Diejomaoh ${ }^{1,2}, \mathrm{Xu} \mathrm{Li}^{1}$ \& Hung-Ling (Stella) Liu ${ }^{1}$ \\ ${ }^{1}$ South Dakota State University, Brookings, South Dakota, USA \\ ${ }^{2}$ Red Lobster, Sioux Falls, South Dakota, USA \\ Correspondence: Xu Li, College of Education and Human Sciences, South Dakota State University, Wagner Hall \\ 431, Box 2275A, Brookings, South Dakota, USA. E-mail: xu.li@sdstate.edu
}

Received: March 4, 2020

doi:10.5539/ijbm.v15n7p1

\author{
Accepted: May 1, 2020 \\ Online Published: June 4, 2020 \\ URL: https://doi.org/10.5539/ijbm.v15n7p1
}

\begin{abstract}
A clear understanding of destination image is crucial for developing effective marketing and positioning strategies. The purpose of the study is to examine the images of Brookings perceived by actual tourists. An online questionnaire was developed and sent to email subscribers of the largest local event center. A total of 344 valid responses were received. Overall tourists had positive perceptions of Brookings as a tourism destination. The study identified six Brookings' image dimensions, including Outdoor Activities and Natural Scenery, Atmosphere, Tourism Infrastructure, Value for Money and Convenience, Historic Attractions, and College Town Style. The social and cultural environment is the most favored element in Brookings. As a college town, Brookings was differentiated from other rural tourism destinations. It is suggested that the city and the university work in partnership to increase visitation both to the campus and the community. To enhance Brookings' image, destination marketers should focus on the low-rated image items and incorporate them in destination marketing materials.
\end{abstract}

Keywords: Brookings, cognitive image, college town, destination image, rural tourism

\section{Introduction}

\subsection{Tourism Development in Rural Areas}

Tourism development has long been recognized as an alternative approach to revitalizing rural America (Akin, Shaw, \& Spartz, 2015; Gartner, 2004). Rural tourism diversifies and enhances the local economy, provides employment and income, improves infrastructure and thus betters residents' quality of life. Rural tourism is usually built upon existing local resources, such as the natural environment, agriculture-based activities and cultural heritage. Rural tourism is considered sustainable in the sense that its development protects the local environment and promotes the local heritage and tradition (Haven-Tang \& Sedgley, 2014).

Tourists have demonstrated an increasing interest in rural tourism. According to the U.S. Travel Association (2019), rural sightseeing ranked one of the top leisure travel activities for the U.S. domestic travelers in each of the three consecutive years between 2016 and 2018. Rural destinations are perceived as places of safety and tradition, surrounded by open space, natural beauty and friendly people, and thus draw those who seek to escape from cities, relax in tranquil environment, enjoy natural scenery and appreciate local culture (Campón-Cerro, Hernández-Mogollón, \& Alves, 2017; Gartner, 2004; Haven-Tang \& Sedgley, 2014).

Tourism has become an important and fast-growing industry in rural areas, especially in the Midwestern, agriculture states (Akin et al., 2015). These rural areas have similar resources in terms of landscape, custom and food. As numerous rural communities turn to tourism to boost economy, they face the challenge of distinguishing themselves in the competitive marketplace. Thus, it is crucial for a rural destination to create an identity and develop differentiated products in order to sustain tourism growth.

\subsection{Tourism Destination Image}

Researchers have demonstrated that image is a valuable part of destination marketing and branding strategies (Baloglu \& McCleary, 1999; Chi \& Qu, 2008; Kim, 2018). Destination image is commonly viewed as impressions or perceptions of a place (Echtner \& Ritchie, 1993). It plays an important role in people's perception 
of a destination and their likelihood to visit and re-visit. Understanding the image of a destination is crucial to its marketing success. An analysis of destination image can help rural destinations create unique products and achieve competitive advantage (Campón-Cerro et al, 2017; Greaves \& Skinner, 2010).

Destination image is defined as the sum of beliefs, ideas and impressions that an individual has of a destination (Crompton, 1979). Due to its strong impacts on tourists' destination choice, subsequent evaluation and future behavior intention, destination image has been widely discussed in the literature (Campón-Cerro et al., 2017; Chi \& Qu, 2008; Kim, 2018; Tasci \& Gartner, 2007). Researchers agreed that destination image consists of two interrelated components: Cognitive and affective (Baloglu \& McCleary, 1999; Beerli \& Martin, 2004; Gartner, 1993; Stylidis, Shani, \& Belhassen, 2017). The cognitive component of the image refers to tourists' beliefs and knowledge about destination attributes or features (e.g., how individuals think about the people, infrastructure, climate, scenery at the destination). Whereas, the affective component of the image refers to tourists' emotion and feelings about a destination (e.g., how pleasant or restful the destination is). Combined together, these two components create an overall image which can be positive or negative (Beerli \& Martin, 2004; Polo et al., 2012; Stylidis et al., 2017). Previous literature also highlights the importance of the cognitive component. On the basis of their knowledge of a destination, tourists develop evaluative responses to the destination. The cognitive component is an antecedent of the affective component (Polo et al., 2012). The cognitive images are observable, measurable and descriptive, and hence, provide specific and explanatory information for a destination to identify the uniqueness and target market (Kim, 2018). Therefore, this study focuses on the cognitive image of a rural destination.

Destination image is believed to be a combination of both positive and negative perceptions. Destinations with more positive images are more likely to be considered in tourist decision-making process. Moreover, researchers affirm the positive relationship between destination image and consumption behavior (Chi \& Qu, 2008; Stylidis et al., 2017). More favorable images will lead to higher customer satisfaction, and thereby more positive behavior intentions (Campón-Cerro et al., 2017; Chen \& Tsai, 2007; Lin et al, 2007). Hence, positive images can serve as differentiating factors and help destinations discern themselves from competitors (Sónmez \& Sirakaya, 2002).

Tourists acquire destination images through a variety of information sources. Gunn (1972) categorized the image formation process into two main stages: Organic and induced. The organic image develops as a result of the daily exposure to non-commercial sources such as newspaper reports, magazine articles, TV programs, books, education, and the information from friends and relatives. The induced image forms because of the influence by destination marketing and promotional activities. Depending on the information sources, destination image can be either primary or secondary (Phelps, 1986). The former develops internally through actual experience or visitation of the destination whereas the latter forms because of the external information received and processed before experiencing a destination (e.g., advertisements, publicity, travel brochure, news report, word of mouth, etc.). Echtner and Ritchie (1993) indicated the differences between primary image and secondary image, and suggested future researchers separate the images of visitors and non-visitors. Compared with the secondary image, the primary image, held by actual visitors, tends to be more realistic, complex and differentiated (Baloglu \& McCleary, 1999; Beerli \& Martin, 2004). In this respect, the current study examines the images perceived by actual visitors.

\subsection{Brookings as a Rural Tourism Destination}

Tourism destination image has been one of the most popular topics in tourism research literature (Pike \& Kotsi, 2016). Previous research has examined a variety of destinations, ranging from countries, states/provinces, cities, to specific locations (Nghiem-Phu, 2014). Most of them focused on well-known features or attractions at national or international level rather than regional tourist attractions or small towns. As more and more rural communities attempt to use tourism as a means of community development and economic engine, it is important for the rural destinations to understand their destination image and differentiate themselves from each other (Tsundoda \& Mendlinger, 2009).

Combining natural and cultural attractions and collegiate atmosphere and vibe, a college town in rural areas, such as Brookings, shows unique potential as a tourism destination. The city of Brookings is located on the eastern side of South Dakota, about 15 miles west of the Minnesota border. It is the $4^{\text {th }}$ largest city in the state of South Dakota with a population of 23,471 ("Brookings," n.d.). Brookings is home to South Dakota State University (SDSU), the largest institution of higher education in the state. As a result, the city attracts lots of student visitors and their families. Brookings is also among the best and safest small towns to live in the United States ("Top 100 Places to Live," 2018). The community offers a variety of attractions ranging from museums 
and parks to events and entertainment.

As a growing community, Brookings has recognized the importance of the tourism industry and the needs for attracting visitors. This was signified by the opening of the Swiftel Center in 2001 and the creation of an independent Convention \& Visitors Bureau (CVB) in 2012 ("Who We Are," n.d.). The scale and importance of Brookings' tourism industry was highlighted in 2017 with visitor spending of US\$103.41 million and the \#1 ranking in the Glacial Lakes and Prairies region of South Dakota (Tourism Economics, 2017). Visitor spending have increased by $12.59 \%$ since 2014 . However, despite continuous effort, a recent report has shown that visitor spending decreased by $4.2 \%$ in 2018 (Tourism Economics, 2018). Given the global trends that rural destinations are in a quite competitive environment (Greaves \& Skinner, 2010; Polo, Frías, \& Rodríguez, 2012), it is necessary to conduct research to understand the destination, identify competitive advantages and thereby develop sustainable strategies. Marketing rural destinations should be guided by a thorough analysis of destination image.

Unfortunately, little is yet known about the destination image of Brookings, a college town in rural area (whether it is positive, negative, or non-existent). This is problematic for the long-term development of the tourism industry, especially in today's highly competitive tourism market. Therefore, the purpose of the study is to examine the image of Brookings, South Dakota as a rural tourism destination in the minds of the U.S. domestic travelers. Two research questions are addressed: (1) what are tourists' cognitive images of Brookings as a destination? (2) what are the positive and negative aspects of Brookings' image? The results of the study help to understand rural tourism destination image and provide college towns with guidance on tourism marketing strategies.

\section{Methods}

\subsection{Data Collection and Sampling}

The online survey was distributed between September and December of 2018 through emails by the largest event venue in Brookings. The event center hosts various types of events annually and has a database of customers who had signed up to receive emails about upcoming events and sales. An email invitation with the survey link was sent to 8,370 subscribers. Only those who were 18 years or older and visited Brookings from March 2017 to May 2018 were qualified to participate in the survey. A follow-up email was sent out in November to remind event participants of the survey.

\subsection{Instrument and Measures}

To assess the cognitive images of Brookings, an online survey was developed and comprised three sections: 1) trip characteristics; 2) destination image; and 3) tourist demographic information. The trip characteristics questions included purpose of the trip, traveling parties, length of stay and attraction visited. Several steps were employed in order to develop an attribute-based scale measuring the cognitive images of Brookings. First, a comprehensive review of literature (e.g., Chen \& Kerstetter, 1999; Chi \& Qu, 2008; Echtner \& Ritchie, 1993; Jenkins, 1999) resulted in a list of attributes which theoretically measure destination image. Secondly, content analysis of local promotion print and websites (e.g., the website of Brookings CVB) were conducted to ensure the image scale captures various aspects of tourists' perceptions of Brookings as a tourism destination. Then local tourism professionals were consulted to confirm the appropriateness of the list of image items. The finalized image scale consists of 43 attributes. They were rated on a 7-point Likert scale where $1=$ Strongly Disagree and $7=$ Strongly Agree. The demographic questions ask respondents about their gender, age, level of education, occupation and household income.

\subsection{Data Analysis}

Data were analyzed using the IBM Statistical Package for the Social Sciences 25. Descriptive analysis was first conducted to understand the personal and trip characteristics of the respondents. Then exploratory factor analysis (EFA) was employed to identify the underlying dimensions of destination image of Brookings, SD. Promax rotation was applied to simplify the interpretation which minimized the number of variables with high loadings on each factor. The number of factors was determined by eigenvalues $(>1)$ and items were selected with the factor loadings greater than .40 for each identified dimension (Stevens, 2012).

\section{Results}

\subsection{Demographic Profile}

A total of 344 valid responses was obtained. As shown in Table 1, the gender distribution was $75.9 \%$ females and $23.0 \%$ males. The vast majority $(67.1 \%)$ of respondents were aged between 22 and 50 . About $41.0 \%$ of the respondents had some college degree, $34.3 \%$ had college education, $12.5 \%$ received graduate school education, 
and $10.2 \%$ completed high school. A large portion (74.1\%) of the respondents held a full-time position. More than $60 \%$ of the respondents had an annual household income of $\$ 50,000$ or more.

Table 1. Respondents' demographic profile $(\mathrm{N}=344)$

\begin{tabular}{lll}
\hline Demographic variable & Frequency & $\%$ \\
\hline Gender & & \\
$\quad$ Female & 261 & 75.9 \\
$\quad$ Male & 79 & 23.0 \\
Age & & \\
$\quad$ Younger than 22 & 16 & 4.7 \\
$22-35$ & 104 & 30.2 \\
$36-50$ & 127 & 36.9 \\
$51-65$ & 84 & 24.4 \\
65+ & 9 & 2.6 \\
Education & & \\
Less than high school & 3 & 0.9 \\
High school & 35 & 10.2 \\
Some college/Associate's degree & 141 & 41.0 \\
Bachelor's degree & 118 & 34.3 \\
Master's degree & 36 & 10.5 \\
Doctorate degree & 7 & 2.0 \\
Occupation & & \\
Student & 20 & 5.8 \\
Housework & 5 & 1.5 \\
Full-time employed & 255 & 74.1 \\
Part-time employed & 28 & 8.1 \\
Unemployed & 5 & 1.5 \\
Retired & 18 & 5.2 \\
Household income & & \\
Less than $\$ 25,000$ & 32 & 9.3 \\
\$25,000-\$49,999 & 61 & 17.7 \\
\$50,000-\$74,999 & 64 & 20.1 \\
\$75,000-\$99,999 & 74 & 18.6 \\
\$100,000 or more & & 21.5 \\
\hline
\end{tabular}

\subsection{Trip Characteristics}

Attending special events, vacation/pleasure and visiting family \& friends were the top three primary purposes of the visit to Brookings (Table 2). It is understandable that more than half $(58 \%)$ of respondents indicated that their primary purpose of the visit was attending special events, for the survey was distributed to customers of the local event center. When asked about travelling party, about $52 \%$ said they traveled with family/friends without children, followed with family/friends and children (37.8\%), and travel alone $(9.6 \%)$. The results also explained why Children's Museum of South Dakota was the most visited tourism attraction (38.4\%). It should be noted that four of the most-visited attractions were university based. They were SDSU Dairy Bar (26.2\%), McCrory Gardens (23.3\%), South Dakota Art Museum (7.8\%), and South Dakota Agricultural Heritage (5.8\%). Overall, respondents paid a short visit to Brookings since less than $15 \%$ stayed in Brookings more than one night. 
Table 2. Respondents' trip Characteristics $(\mathrm{N}=344)$

\begin{tabular}{lll}
\hline Trip characteristic & Frequency & $\%$ \\
\hline Purpose of trip & & \\
Attending special events & 201 & 58.4 \\
Vacation/pleasure & 101 & 29.4 \\
Visiting family \& friends & 25 & 7.3 \\
Shopping & 8 & 2.3 \\
Convention/exhibition & 6 & 1.7 \\
Business/professional & 3 & 0.9 \\
Traveling party & & \\
Alone & 33 & 9.6 \\
With family/friends and children & 130 & 37.8 \\
With family/friends without children & 177 & 51.5 \\
With business associates & 1 & 0.3 \\
With organized group & 3 & 0.9 \\
Number of nights stayed in Brookings & & \\
0 & 179 & 52.0 \\
1 & 115 & 33.4 \\
2 & 33 & 9.6 \\
3 & 8 & 2.3 \\
4 & 1 & 0.3 \\
5 & 0 & 0 \\
6 or more & 8 & 2.3 \\
Tourism attractions visited* & & \\
Children's Museum of South Dakota & 132 & 38.4 \\
Nick's Hamburger Shop & 112 & 32.6 \\
SDSU Diary Bar & 90 & 26.2 \\
McCrory Gardens & 80 & 23.3 \\
South Dakota Art Museum & 27 & 7.8 \\
South Dakota Agricultural Heritage Museum & 20 & 5.8 \\
Brookings County Outdoor Adventure Center & 19 & 5.5 \\
Brookings Arts Council & 8 & 2.3 \\
\hline
\end{tabular}

*Respondents can choose more than one answer.

\subsection{Image Dimensions}

An exploratory factor analysis was performed on the 43 image attributes to determine the underlying dimensionality of destination image. The principal axis factoring method with a promax rotation was adopted. The results of Kaiser-Myer-Olkin (KMO) test indicated the factoring structure was appropriate $(\mathrm{KMO}=0.96)$. Six factors with Eigenvalues greater than one were retained, explaining $71.93 \%$ of the variance. Table 3 illustrated factor loadings, means, eigenvalues, percentage of explained variance, and reliability coefficients.

A total of six cognitive image dimensions were identified and named based on the core variables constituted them: Outdoor Activities and Natural Scenery, Atmosphere, Tourism Infrastructure, Value for Money and Convenience, Historic Attractions, and College Town Style. Cronbach's alpha reliability coefficients ranged from a high of 0.94 (Tourism Infrastructure) to a low of 0.85 (Historic Attractions), indicating the variables were highly correlated within their respective factor groups. Six image items were eliminated due to cross loadings or loadings below 0.4 . The six items were wonderful retreat from daily life, all the necessary components to attract seniors, gorgeous gardens, pleasant weather, diverse community for everyone, simple lifestyle. 
Table 3. Destination image dimensions of Brookings, SD

\begin{tabular}{|c|c|c|c|c|c|}
\hline Image item & $\begin{array}{l}\text { Factor } \\
\text { loading }\end{array}$ & Mean & Eigenvalue & $\begin{array}{l}\text { Variance } \\
\text { explained (\%) }\end{array}$ & $\begin{array}{l}\text { Cronbach's } \\
\text { Alpha }\end{array}$ \\
\hline Factor 1 Outdoor activities and natural scenery & & & 22.87 & 53.19 & 0.93 \\
\hline Exciting water sports/activities (boating, fishing, etc.) & 0.92 & 4.33 & & & \\
\hline Terrific place for hiking/picnicking/camping/biking & 0.82 & 4.52 & & & \\
\hline Picturesque parks and lakes and rivers & 0.71 & 4.59 & & & \\
\hline Enormous opportunities for outdoor recreations & 0.71 & 4.70 & & & \\
\hline Good facilities for golfing & 0.66 & 4.62 & & & \\
\hline Breathtaking scenery and natural attractions & 0.60 & 4.37 & & & \\
\hline Romantic setting for wedding and honeymoon & 0.56 & 4.13 & & & \\
\hline Grand mean & & 4.47 & & & \\
\hline Factor 2 Atmosphere & & & 2.70 & 6.27 & 0.93 \\
\hline Family-friendly environment & 0.91 & 5.77 & & & \\
\hline Safe and secure environment & 0.85 & 5.49 & & & \\
\hline Clean and tidy environment & 0.77 & 5.48 & & & \\
\hline Friendly and helpful local people & 0.72 & 5.45 & & & \\
\hline Tranquil and restful atmosphere & 0.60 & 5.06 & & & \\
\hline Good variety of activities for children & 0.50 & 5.21 & & & \\
\hline Easy access to the area & 0.44 & 5.53 & & & \\
\hline Grand mean & & 5.43 & & & \\
\hline Factor 3 Tourism infrastructure & & & 1.67 & 3.89 & 0.94 \\
\hline Wide variety of entertainment & 0.83 & 5.08 & & & \\
\hline Wide array of shows/exhibitions/fairs & 0.74 & 4.92 & & & \\
\hline Colorful nightlife & 0.72 & 4.82 & & & \\
\hline Wide choice of accommodations & 0.70 & 4.85 & & & \\
\hline Excellent quality and fun country/western music & 0.66 & 4.85 & & & \\
\hline Tempting cultural events and festivals & 0.60 & 4.73 & & & \\
\hline Wide variety of shopping facilities & 0.57 & 4.10 & & & \\
\hline Wide selection of restaurants/cuisine & 0.50 & 4.76 & & & \\
\hline Plentiful activities for both men and women & 0.49 & 5.12 & & & \\
\hline Exquisite local arts and crafts & 0.48 & 4.48 & & & \\
\hline Grand mean & & 4.77 & & & \\
\hline Factor 4 Value for money and convenience & & & 1.42 & 3.30 & 0.92 \\
\hline Good value for money & 0.78 & 4.93 & & & \\
\hline Reasonable price for food and accommodation & 0.67 & 5.07 & & & \\
\hline Availability of travel information & 0.65 & 4.77 & & & \\
\hline Available parking downtown & 0.56 & 4.65 & & & \\
\hline Reasonable price for attractions and activities & 0.48 & 5.04 & & & \\
\hline Quality service & 0.41 & 5.25 & & & \\
\hline Grand mean & & 4.95 & & & \\
\hline Factor 5 Historic attractions & & & 1.17 & 2.72 & 0.85 \\
\hline Vintage buildings & 0.89 & 4.66 & & & \\
\hline Distinctive history and heritage & 0.80 & 4.68 & & & \\
\hline Interesting museums/exhibits & 0.50 & 5.09 & & & \\
\hline Grand mean & & 4.81 & & & \\
\hline Factor 6 College town style & & & 1.10 & 2.56 & 0.88 \\
\hline Good learning opportunity & 0.68 & 5.16 & & & \\
\hline Jackrabbits pride & 0.67 & 5.56 & & & \\
\hline University campus tour & 0.60 & 4.77 & & & \\
\hline High standard of living & 0.46 & 5.04 & & & \\
\hline Grand mean & & 5.13 & & & \\
\hline
\end{tabular}

The ratings of image items ranged from 4.10 (wide variety of shopping facilities) to 5.77 (family friendly atmosphere). To compare the six dimensions, a mean score for each of the six dimensions was computed by 
averaging the image items representing the dimension. The highest rated image dimension was Atmosphere $(M=$ 5.43), followed by College Town Style $(M=5.13)$, Value for Money and Convenience $(M=4.95)$, Historic Attractions $(M=4.81)$, Tourism Infrastructure $(M=4.77)$, and Outdoor Activities \& Natural Scenery $(M=4.47)$.

\section{Discussion and Conclusion}

Tourism development contributes to rural revitalization and the diversity of rural economy. As numerous rural areas turn to tourism development to boost and diversify their economy, it is vital for them to employ differentiation strategies. A necessary first step in this direction is the study of rural tourism destination image. The current study has attempted to measure and evaluate the cognitive images of Brookings perceived by actual tourists. The results indicated a total of six dimensions representing Brookings as a tourism destination. They were Outdoor Activities and Natural Scenery, Atmosphere, Tourism Infrastructure, Value for Money and Convenience, Historic Attractions, and College Town Style. The results were consistent with previous studies that rural tourism destinations were characterized by peace and tranquility, safety, quality and price of service, and friendliness (Akin et al., 2015; Polo et al., 2012).

The findings of the study provided some guidance for the success of marketing Brookings as a tourism destination. Overall, Brookings had been positively positioned in the minds of tourists. The social and cultural environment is the most favored element in Brookings. Tourists perceived Brookings family-friendly, safe and secure, clean and tide, tranquil and restful. Moreover, the results revealed that South Dakota State University helped set the cultural tone and differentiate Brookings from other rural tourism destinations. The University has offered many educational, recreational and cultural activities, and attracted people to visit the family of Jackrabbit (SDSU mascot) and the city as well. These key features should be highlighted and communicated effectively in future tourism promotional materials. It is also suggested that the city and the university work in partnership to increase visitation both to the campus and the community. For instance, the local CVB and SDSU colleges/departments can collaborate to bring regional and national association conferences to Brookings or create events to drive traffic. In Fall semester when new students and parents come, the CVB and the university can work together to inform them of what to see and do in Brookings community and take them on tours of the city. Further, the destination marketing organization could use previous visitors as city ambassadors to promote Brookings to potential visitors. In today's digital era, the destination can easily create a contest online, inviting tourists to post pictures about their visits and let other people vote for the winners. The activity not only inspires tourists' interests in Brooking but also encourages them to dig more about the destination.

Destination marketers should strive to enhance Brookings' image, with focus on the low-rated image items and dimensions. For instance, the Outdoor Activities and Natural Scenery dimension had a lower and more neutral mean score. The reason might be lack of awareness of these activities and short stay in Brookings. According to Table 2, more than half of visitors didn't stay overnight in Brookings. They came and left right after an event. Therefore, they didn't have chance to participate in any of the outdoor activities offered in Brookings. It is suggested in the future the message about outdoor activities be incorporated in destination marketing materials. Brookings may also host some events at its outdoor venues and create opportunities for tourists to learn more about the venues and activities.

As with any empirical study, this article is not immune from limitations. First, this study was mainly focused on the cognitive images of Brookings. In order to obtain a full picture of destination image of Brookings, future studies can assess the affective images of Brookings. Second, the respondents of the study were primarily event attendees. Their perceptions might be different from other types of tourists, such as vacationer, business travelers. It would be interesting to include other types of tourists in future studies and compare the image differences among the groups.

\section{Acknowledgements}

This research is funded by the 2018 Research and Scholarship Found at South Dakota State University (SDSU). The authors acknowledge the assistance from Brookings Conventions and Visitors Bureau (CVB) and Swiftel Center in questionnaire development and data collection, and the support from the USDA National Institute of Food and Agriculture (NIFA), Hatch project (\#1016822) for research preparation and dissemination.

\section{References}

Akin, H., Shaw, B. R., \& Spartz, J. T. (2015). Promoting economic development with tourism in rural communities: Destination image and motivation to return or recommend. Journal of Extension, 53(2), 1-14.

Baloglu, S., \& McCleary, K. (1999). U.S. international pleasure travelers' images of four Mediterranean destination: A comparison of visitors and non-visitors. Journal of Travel Research, 38(2), 144-152. 
https://doi.org/10.1177/004728759903800207

Beerli, A., \& Martin, J. D. (2004). Factors influencing destination image. Annals of Tourism Research, 31(3), 657-681. https://doi.org/10.1016/j.annals.2004.01.010

Brookings, South Dakota. Highlights. (n.d.). Retrieved from https://www.bestplaces.net/city/south_dakota/brookings

Campón-Cerro, A. M., Hernández-Mogollón, J. M., \& Alves, H. (2017). Sustainable improvement of competitiveness in rural tourism destinations: The quest for tourist loyalty in Spain. Journal of Destination Marketing \& Management, 6(3), 252-266. https://doi.org/10.1016/j.jdmm.2016.04.005

Chen, C., \& Tsai, D. (2007). How destination image and evaluative factors affect behavioral intentions. Tourism Management, 28(4), 1115-1122. https://doi.org/10.1016/j.tourman.2006.07.007

Chen, P. J., \& Kerstetter, D. L. (1999). International students' image of rural Pennsylvania as a travel destination. Journal of Travel Research, 37(4), 256-266. https://doi.org/10.1177/004728759903700307

Chi, C. G. Q., \& Qu, H. (2008). Examining the structural relationships of destination image, tourist satisfaction and destination loyalty: An integrated approach. Tourism Management, 29(4), 624-636. https://doi.org/10.1016/j.tourman.2007.06.007

Crompton, J. L. (1979). An assessment of the image of Mexico as a vacation destination and the influence of geographical location upon that image. Journal of Travel Research, 17(4), 18-23. https://doi.org/10.1177/004728757901700404

Echtner, C. M., \& Ritchie, J. R. (1993). The measurement of destination image: An empirical assessment. Journal of Travel Research, 31(3), 3-13. https://doi.org/10.1177/004728759303100402

Gartner, W. (2004). Rural tourism in the USA. International Journal of Tourism Research, 6(3), 151-164. https://doi.org/10.1002/jtr.481

Greaves, N., \& Skinner, H. (2010). The importance of destination image analysis to UK rural tourism. Marketing Intelligence Planning, 28(4), 486-507. https://doi.org/10.1108/02634501011053586

Gunn, C. A. (1972). Vacationscape: Designing tourist regions. Austin, TX: University of Texas.

Haven-Tang, C., \& Sedgley, D. (2014). Partnership working in enhancing the destination brand of rural areas: A case study of made in Monmouthshire, Wales, UK. Journal of Destination Marketing \& Management, 3(1), 59-67. https://doi.org/10.1016/j.jdmm.2013.12.001

Jenkins, O. H. (1999). Understanding and measuring tourist destination images. International Journal of Tourism Research, $1(1)$

$1-15$. https://doi.org/10.1002/(SICI)1522-1970(199901/02)1:1<1::AID-JTR143>3.0.CO;2-L

Kim, J. H. (2018). The impact of memorable tourism experiences on loyalty behaviors: The mediating effects of destination image and satisfaction. Journal of Travel Research, 57(7), 856-870. https://doi.org/10.1177/0047287517721369

Lin, C. H., Morais, D. B., Kerstetter, D. L., \& Hou, J. S. (2007). Examining the role of cognitive and affective image in predicting choice across natural, developed and theme-park destinations. Journal of Travel Research, 46(2), 183-194. https://doi.org/10.1177/0047287506304049

Nghiem-Phu, B. (2014). A review of destination image studies from 2008 to 2012. European Journal of Tourism Research, 8, 35-65.

Phelps, A. (1986). Holiday destination image-The problem of assessment: An example developed in Menorca. Tourism Management, 7(3), 168-180. https://doi.org/10.1016/0261-5177(86)90003-8

Pike, S., \& Kotsi, F. (2016). Stopover destination image - Using the Repertory Test to identify salient attributes. Tourism Management Perspectives, 18, 68-73. https://doi.org/10.1016/j.tmp.2016.01.005

Polo, A. I., Frías, D. M., \& Rodríguez, M. A. (2012). Validation of cognitive image dimensions for rural tourist destinations: A contribution to the management of rural tourist destinations. Journal of Vacation Marketing, 18(4), 261-273. https://doi.org/10.1177/1356766712449351

Sónmez, S., \& Sirakaya, E. (2002). A distorted destination image? The case of Turkey. Journal of Travel Research, 41(2), 185-196. https://doi.org/10.1177/004728702237418

Stevens, J. P. (2012). Applied multivariate statistics for the social sciences. Routledge. 
Stylidis, D., Shani, A., \& Belhassen, Y. (2017). Testing an integrated destination image model across residents and tourists. Tourism Management, 58(1), 184-195. https://doi.org/10.1016/j.tourman.2016.10.014

Tasci, A. D. A. and Gartner, W. C. (2007). Destination image and its functional relationships. Journal of Travel Research, 45(4), 413-425. https://doi.org/10.1177/0047287507299569

Top 100 Places To Live. Brookings, South Dakota. (2018). Retrieved from https://ivability.com/best-places/top-100-best-places-to-live/2018/sd/brookings

Tourism Economics. (2017). The Economic impact of tourism in South Dakota. Retrieved from https://sdvisit.com/sites/default/files/2018-06/17EcoImp_Tourism_Economics.pdf

Tourism Economics. (2018). The Economic impact of tourism in South Dakota, county and region analysis. Retrieved from https://sdvisit.com/sites/default/files/2018-08/15TSA_Tourism_Economics_Counties.pdf

Tsundoda, T., \& Mendlinger, S. (2009). Economic and social impact of tourism on a small town: Peterborough New Hampshire. Journal of Service Science and Management, 2(2), 61-70.

U. S. Travel Association (2019). U.S. Travel Answer Sheet. Available https://www.ustravel.org/system/files/media_root/document/Research_Fact-Sheet_US-Travel-Answer-Shee t.pdf

Who We Are. (n.d.). Retrieved from https://visitbrookingssd.com/about/history

\section{Copyrights}

Copyright for this article is retained by the author(s), with first publication rights granted to the journal.

This is an open-access article distributed under the terms and conditions of the Creative Commons Attribution license (http://creativecommons.org/licenses/by/4.0/). 